\title{
MENJAGA TOLERANSI MELALUI PEDIDIKAN MULTIKULTURALISME
}

\author{
Muhammad Ridwan Effendi \\ Universitas Negeri Jakarta, \\ Jl. R.Mangun Muka Raya Rawamangun Jakarta Timur \\ muhammadridwan@unj.ac.id \\ Yoga Dwi Alfauzan \\ Universitas Negeri Jakarta, \\ Jl. R.Mangun Muka Raya Rawamangun Jakarta Timur \\ yoga.alfauzan4@gmail.com \\ Muhammad Hafizh Nurinda \\ Universitas Negeri Jakarta, \\ Jl. R.Mangun Muka Raya Rawamangun Jakarta Timur \\ apizn99@gmail.com
}

DOI: 10.46781/al-mutharahah.v18i1.175

\begin{abstract}
Multicultural education is the Indonesian education system that began even during the time of Ki Hajar Dewantara. This education system is able to end the view of differences between race, religion, ethnicity, culture, language and so on if it is implemented properly. In various cases in Indonesia, attitudes of intolerance often spice up the problem. Through this multicultural education, it is hoped that it will be able to provide a deep meaning about this attitude of tolerance. This research was conducted using the literary method obtained from library data, books, journals, websites and all other library sources. The type of research the writer uses is qualitative research, where the research is carried out through a narrower but deeper scope. The author will describe tolerance as an attitude or nature of respect and respect for others and multicultural education that emphasizes the principles of equality. The author states four ways that can be taken in maintaining tolerance through multicultural education, namely deepening the meaning of tolerance in learning, providing discussions about various cultures, increasing awareness of the social sphere, and trying to open the thinking patterns of students so that echo chambers do not occur.
\end{abstract}

Keywords: Tolerance; Intolerance; Multicultural Education; Difference; Education system.

\begin{abstract}
Abstrak
Pendidikan multikultural merupakan sistem pendidikan Indonesia yang di mulai bahkan pada saat masa Ki Hajar Dewantara. Sistem pendidikan ini mampu mengakhiri pandangan perbedaan antara ras, agama, etnis, budaya, bahasa dan lain sebagainya jika diterapkan dengan baik. Dalam berbagai kasus di Indonesia, sikap intoleransi kerap kali membumbui permasalahan tersebut. Melalui pendidikan multikultural ini diharapkan mampu memberikan makna mendalam mengenai sikap toleransi tersebut. Penelitian ini dilakukan menggunakan metode litelatur yang diperoleh dari data pustaka, buku-buku, jurnal, website dan segala sumber pustaka lainya. Jenis penelitian yang digunakan penulis adalah penilitian kualitatif, dimana penelitian yang dilakukan melalui lingkup yang lebih sempit akan tetapi lebih mendalam. Penulis akan memaparkan toleransi sebagai suatu sikap atau sifat menghargai dan menghormati orang lain dan pendidikan multikultural yang menekankan akan prinsip-prinsip
\end{abstract}


kesamaan. Penulis menyatakan empat cara yang dapat ditempuh dalam menjaga toleransi melalui pendidikan multikultural, yaitu mendalami arti toleransi dalam pembelajaran, memberikan diskusi mengenai ragam kebudayaan, meningkatkan kepedulian pada ranah sosial, serta berusaha membuka pola pemikiran siswa/mahasiswa agar tidak terjadi echo chamber.

Kata Kunci: Toleransi; Intoleransi; Pendidikan Multikultural; Perbedaan; Sistem Pendidikan.

\section{A. PENDAHULUAN}

Toleransi merupakan bentuk tertinggi akan sebuah keyakinan dan dapat menjadi sebuah kenyataan jika seseorang mengasumsikan perbedaan. Sikap toleransi biasa ditunjukan seseorang dalam suatu perbedaan pendapat, budaya, ras, agama, suku, bahasa, bahkan suatu bangsa ${ }^{1}$. Toleransi yang penulis maksud adalah toleransi yang akan terwujud dalam sistem pendidikan multikulturalisme.

Sistem pendidikan multikultural sudah diterapkan di Indonesia oleh Ki Hajar Dewantara. Bukan tak asing lagi bagi bangsa Indonesia yang majemuk dalam memahami pentingnya pendidikan multikultural bagi terselenggaranya pendidikan. Pendidikan multikultural juga sangat penting bagi terselenggaranya demokrasi dan mengatasi permasalahan yang ada. Sistem ini seakan menjadi bagian yang tak terpisahkan dan menjadi sebuah jembatan terwujudnya pendidikan yang maju dan berkebudayaan. Sistem pendidikan multikultural adalah sistem pembangun dan penopang kebudayaan Indonesia.

Penulis sangat mempertimbangkan pentingnya pendidikan multikultural dalam menjaga toleransi bangsa yang kian terasa mulai terkikis. Banyaknya perbedaan pendapat dan pemikiran dari luar yang mempengaruhi pemikiran generasi bangsa akibat globalisasi pun patut kita waspadai. Penulis mencoba mengulas toleransi dan pendidikan multikulturalisme ini melalui sebuah studi litelatur penelitian kualitatif. Pertama, apa itu toleransi? Pengertian ini sangat diperlukan untuk mengkaji apakah toleransi hanya sebatas sebuah keyakinan atau idealisme. Kedua, apa itu pendidikan multikultural? Dengan memahami apa itu pendidikan multikultural dan bermacam pandangan dari berbagai tokoh, penulis berharap kita dapat memahami tujuan dan manfaat dari diadakannya pendidikan multikultural di Indonesia. Ketiga, apa pentingnya toleransi dalam pendidikan multikulturalisme? Ini merupakan pertanyaan utama yang menjadi topik dari kajian penelitian penulis.

Dengan dilatarbelakangi oleh penugasan dalam mata kuliah pendidikan agama Islam serta dorongan pribadi penulis untuk memahami sistem pendidikan multikultural. Didasarkan oleh data pustaka, web, jurnal, dan buku-buku terkait, penulis menyusun hasil penelitian tersebut dengan judul "Menjaga Toleransi Melalui Pendidikan Multikulturalisme".

\section{B. METODE PENELITIAN}

Metode penelitian yang digunakan adalah metode penelitian studi litelatur. Penelitian studi litelatur adalah metode penelitian yang bersumber dan menggunakan metode pengumpulan data dari data pustaka, jurnal-jurnal, buku, dan liteltur lainnya yang dapat dijadikan sebagai bahan penelitian ${ }^{2}$. Sedangkan jenis penelitian yang digunakan adalah penelitian kualitatif. Penelitian kualitatif adalah penelitian yang memiliki cakupan lebih kecil juga lebih mendalam dan biasa disajikan dalam bentuk deskripsi maupun narasi ${ }^{3}$.

\footnotetext{
1 Welianto, Ari. 2020. Tujuan dan Manfaat Toleransi. https://www.kompas.com /skola/read/2020/03/06/170000769/tujuan-dan-manfaat-toleransi?page=all

2 Melfianora. 2010. Penulisan Karya Tulis IImiah Dengan Studi Literatur. file://C:/Users/ACER/Downloads/KTI\%20dengan\%20Studi\%20Literatur.pdf

3 Kelas Pintar. 2019. Mengenal Jenis-Jenis Metode Penelitian. https://www.kelaspintar.id/blog/edutech/jenis-metode-penelitian-2566/
} 


\section{PEMBAHASAN}

Pendidikan multikulturalisme memasukan proses potensi manusia untuk menghargai plularisme dan semua keberagamannya ${ }^{4}$. Pendidikan multikutural tidak mengenal adanya perbedaan ras, suku, agama, budaya, dan terus menekankan toleransi dalam setiap pembelajarannya. Dalam konsep plularisme, pendidikan multikultural di dasar kan pada prinsip-prinsip kesamaan manusia ${ }^{5}$.

\section{Pengertian Toleransi}

Toleransi bukan merupakan suatu kata asing yang jarang terdengar oleh sebagian besar masyarakat Indonesia. Pengertian toleransi dalam Kamus Besar Bahasa Indonesia (KBBI) adalah

\section{"bersifat atau bersikap menenggang (menghargai, membiarkan, membolehkan) pendirian (pendapat, pandangan, kepercayaan, kebiasaan, kelakuan, dan sebagainya) yang berbeda atau bertentangan dengan pendirian sendiri ${ }^{6} . "$}

Pengertian tersebut dapat diartikan sebagai sebuah sifat atau sikap yang berasal dari idealisme diri seseorang. Watson (1997) juga mengartikan toleransi sebagai suatu batas ukur yang mengukur penambahan atau pengurangan terhadap suatu hal yang masih diperbolehkan. Dalam pengertiannya tersebut, Watson mengarahkan toleransi bukan sebagai suatu sikap maupun sifat, tetapi lebih terhadap suatu keputusan yang diambil oleh seseorang. Menurut Hasyim (1979), toleransi sendiri merupakan suatu pemberian kebebasan yang dibeikan kepada semua manusia (tanpa terkecuali) atau kepada sesama warga masyarakat yang bertujuan untuk menjalankan keyakinannya atau hanya sekedar mengatur hidupn dalam menentukan nasibnya masing-masing. Dengan catatan, selama seseorang menjalankan dan menentukan sikapnya itu tetap tidak melanggar dan tidak berrtentangan dengan syarat-syarat yang ada atas terciptanya ketertiban dan pendamaian di dalam masyarakat itu sendiri.

Secara ontologis, ide toleransi berakar pada sebuah konsep Latin yang sebenarnya merujuk pada semacam kemampuan fisik yang digunakan untuk 'menanggung' hal-hal yang kurang disenangi. Dalam perkembangannya, ide ini mulai berkembang dalam penggunaan yang sebenarnya berkaitan dengan hubungan antaragama, utamanya dalam kaitan dengan perlindungan dari sebuah prinsip cuius regio, eius religio (barang siapa yang dapat menguasai suatu negeri, berhak pula menetapkan agamanya atas penduduk pada negeri itu). Dalam buku berjudul The Difficulty of Tolerance, Thomas Scanlon (2003) merefleksikan bahwa toleransi sebagai sebuah kesadaran moral yang dimengerti dengan pertanyaan what we owe to each other atau "kita berhutang apa dari sesama kita?".

\footnotetext{
${ }^{4}$ Ibrahim, Rustam. 2013. Pendidikan Multikultural: Pengertian, Prinsip, dan Relevansinya dengan Tujuan Pendidikan Islam. https://journal.iainkudus.ac.id/index.php/Addin/article/view/573/586.

${ }^{5}$ Ibrahim, Rustam. 2013. Pendidikan Multikultural: Pengertian, Prinsip, dan Relevansinya dengan Tujuan Pendidikan Islam. https://journal.iainkudus.ac.id/index.php/Addin/article/view/573/586

${ }^{6}$ Nn. 2020. Kamus Besar Bahasa Indonesia (KBBI).

${ }^{7}$ Aditya, Ivan. 2017. Politik Toleransi. https://www.krjogja.com/angkringan/opini/politik-toleransi/
} 


\section{a. Jenis Toleransi}

Toleransi sendiri dapat dibagi menjadi tiga jenis, yaitu toleransi berpolitik, toleransi beragama, dan toleransi budaya ${ }^{8}$.

\section{1) Toleransi Berpolitik}

Toleransi berpolitik ini lebih mengarah bagaiamana tiap-tiap orang dalam menghargai dan menghargai pendapat politik yang dimiliki oleh orang lainn. Toleransi ini lebih menekankan bagaimana setiap orang bersama-sama menghargai, menghormati, dan saling menjaga hak-hak politiknya masing-masing.

Belakangan ini kita dihadapkan oleh berbagai situasi politik. Tak jarang situasi politik yang muncul cenderung destruktif bagi pembanguna bangsa kita. Berbagai pendapat dan pandangan juga muncul dalam menghadapi situasi politik tersebut Dalam negara demokrasi ini, toleransi sangat diperlukan untuk meghargai hak-hak setiap warga negara dalam menyuarakan pendapatnya terhadap sistem politik di Indonesia.

\section{2) Toleransi Beragama}

Toleransi beragama merupakan suatu sikap menghormati dan menghargai setiap perbedaan agama yang ada. Toleransi dalam beragama meliputi saling menghormati hak setiap orang dalam memilih agama sesuai kepercayaan dan keyakinannya masing-masing. Semua itu tercermin dalam pancasila sila pertama yang berbunyi, "Ketuhanan yang Maha Esa". Bung Karno juga menegaskan toleransi beragama dalam pidatonya pada tanggal 1 Juni 1945:

"... Marilah kita semuanya berTuhan. Hendaklah negara Indonesia ialah negara yang tiap-tiap orangnya dapat menyembah Tuhannya dengan cara yang leluasa. Segenap rakyat hendaknya ber-Tuhan secara berkebudayaan, yakni dengan tiada egoisme-agama ${ }^{9} . .$.

Bung Karno merefleksikan toleransi beragama dalam ketiadaan egoisme-agama sesuai dalam pidatonya tersebut. Bung Hatta juga berpendapat yang sama dalam pidatonya pada peringatan lahirnya Pancasila di Gedung Kebangkitan Nasional tanggal 1 Juni 1977. Bung Hatta berpesan pada bangsa di balik penjelasannya mengenai makna penting dan fungsi dari Sila Pertama Pancasila.

"Dasar Ketuhanan Yang Maha Esa jadi dasar yang memimpin cita-cita negara kita, yang memberikan jiwa kepada usaha menyelenggarakan segala yang benar, adil dan

baik... Ketuhanan Yang Maha Esa tidak lagi hanya dasar hormat menghormati agama masing-masing-masing, melainkan jadi dasar yang memimpin ke jalan kebenaran, kebaikan, kejujuran persaudaraan..."

Bung Hatta meyakini jika dasar "Ketuhanan yang maha Esa" dapat menjadikan bangsa Indonesia menjadi bagsa yang besar jikalau diyakini dengan baik.

\section{3) Toleransi Budaya}

Negara Indonesia yang beraneka ragam budaya ini seolah menjadikan toleransi sebagai suatu kunci untuk dapat hidup rukun satu sama lain. Dengan toleransi sebagai sikap budaya bangsa, tidak ada sikap yang dapat merendahkan atau superioritas

\footnotetext{
${ }^{8}$ Nugroho, Fauzan Tri. 2020. Pengertian Toleransi Secara Umum dan Menurut Ahli, Ketahui Jenis-jenisnya. https://www.bola.com/ragam/read/4409596/pengertian-toleransi-secara-umum-dan-menurut-ahli-ketahuijenis-jenisnya.

${ }^{9}$ Aditya, Ivan. 2017. Politik Toleransi. https://www.krjogja.com/angkringan/opini/politik-toleransi/
} 
antarbudaya, suku, maupun ras. Karena itu, setiap orang harus memandang sama rata terhadap budaya yang lain.

\section{b. Bentuk Toleransi}

Prinsip-prinsip toleransi menurut United Nations of Educational, Scientific, and Cultural Organization (UNESCO) adalah rasa hormat, penerimaan dan penghargaan atau keragaman budaya dunia yang kaya, berbagai bentuk ekspresi diri, dan cara-cara menjadi manusia. Toleransi menurut UNESCO diartikan sebagai kerukunan dalam perbedaan serta suatu sikap atau perilaku manusia yang tidak menyimpang dari aturan, dimana seseorang menghargai atau menghormati setiap tindakan yang dilakukan orang lain.

Sedangkan bentuk toleransi menurut Allport (1954) dalam Suryabrata (1989) bentuk dari toleransi terdiri atas 6 macam $^{10}$, yaitu Conformity tolerance, Character conditioning tolerance, Millitant tolerance, Passive tolerance, Liberalism tolerance, dan Radicalism tolerance.

\section{1) Conformity tolerance}

Toleransi yang terjadi karena suatu masyarakat memang sudah memberikan standar, aturan, atau kode etik tertentu yang mengatur toleransi. Mereka menjadi toleran karena berusaha untuk menerima dengan peraturan yang ada.

\section{2) Character conditioning tolerance}

Toleransi ini terjadi karena seseorang telah mengembangkan suatu bentuk positif organisasi kepribadian yang berfungsi penuh arti dalam totalitas kepribadiannya. Orang-orang ini memiliki penghargaan positif terhadap orag lain, siapapun ia, mereka mempunyai pandangan terhadap dunia yang positif.

\section{3) Militant tolerance}

Toleransi ini berjuang menentang tindakan yang menunjukkan intoleransi. Mereka adalah orang yang benar-benar intoleran dengan intoleransi.

\section{4) Passive tolerance}

Toleransi ini merupakan orang-orang yang sedang berusaha mencari perdamaian dan mengusahakan jalan damai terhadap segenap tindakan intoleransi. Langkah yang mereka ambil dalam menghadapi permasalahan intoleransi biasanya dengan menghasilkan suatu perdamaian bagi seluruh pihak.

\section{5) Liberalism tolerance}

Toleransi ini merupakan orang-orang yang kritis terhadap status quo. Mereka adalah orang menginginkan perubahan sosial cepat yang berkaitan dengan toleansi. Orang yang toleran menginginkan adanya perubahan yang revolusioner terhadap keadaan masyarakat yang dilihatnya sebagai intoleransi.

\section{6) Radicalism tolerance}

- Dalam pengertian politis, radikalisme hampir bermakna sama dengan lieralisme, perbedaanya hanyalah dalam segi intensitasnya yang lebih tinggi dari liberalisme. Orang-orang yang toleran melakukan kritik yang radikalisme (mengakar) terhadap keadaan-keadaan yang dianggapnya intoleran.

\section{Pengertian Pendidikan Multikultural}

Pendidikan multikultural merupakan suatu gerakan pembaharuan sekaligus proses untuk menciptakan lingkungan pendidikan setara untuk seluruh pelajar tanpa memandang ras, suku, agama, status sosial, dan lain sebagainya. Menurut Andersen dan Cusher (1994) dalam Mahfud (2008), pendidikan multikultural diartikan sebagai pendidikan beragam kebudayaan. Sedangkan menurut Hernandez (1989) pendidikan multikultural diartikan sebagai perspektif yang mengakui realitas sosial, politik, dan ekonomi yang dialami oleh tiap-tiap individu dalam pertemuan manusia yang kompleks dan beragam dan merefleksikan pentingnya

10 Triyani, Ely Mei. 2016. Perbedaan Toleransi Antar Umat Beragama Pada Penganut Islam Dan Hindu Di Desa Kongkong Kecamatan Mijen Kota Semarang. https://lib.unnes.ac.id/28734/1/1511412114.pdf 
budaya, ras, seksualitas dan gender, etnisitas, agama, status sosial, ekonomi, dan pengecualian-pengecualian dalam proses pendidikan. Dengan pendapat yang berbeda, menurut Zamroni pendidikan multikultural merupakan suatu bentuk reformasi dari pendidikan yang bertujuan untuk memberikan kesempatan yang setara bagi seluruh siswa/mahasiswa tanpa memandang latar belakangnya, sehingga semua siswa/mahasiswa dapat meningkatkan ke mampuan yang seoptimal sesuai dengan ke tertarikan, minat dan bakat yang dimilikinya.

\section{a. Tujuan Pendidikan Multikulturalisme}

Tujuan utama dari pendidikan multikultural adalah untuk menanamkan sikap simpati, saling menghormati, saling menghargai dan empati terhadap penganut agama dan budaya yang berbeda.

\section{b. Pentingnya Pendidikan Multikulturalisme}

Indonesia adalah negara yang terdiri dari berbagai-ragam masyarakat yang berbeda; seperti agama, suku, ras, kebudayaan, adat istiadat, bahasa, dan lain sebagainya. Hal tersebut menjadikan masyarakat Indonesia sebagai masyarakat yang majemuk. Dalam kehidupan yang beragam ini, menjadi tantangan tersendiri untuk mempersatukan bangsa Indonesia yang majemuk menjadi satu kekuatan yang dapat menjunjung tinggi perbedaan dan keragaman dari masyarakatnya. Hal ini tentunya dapat dilakukan dengan pendidikan multikultural yang ditanamkan kepada mahasiswa lewat pembelajaran di perguruan tinggi. Menurut Hilda (2002), ada tiga tantangan besar dalam melaksanakan pendidikan multikultural di Indonesia, yaitu:

\section{1) Agama, suku bangsa dan tradisi}

Agama secara aktual merupakan ikatan yang sangat terpenting dalam kehidupan masyarakat Indonesia sebagai suatu bangsa. Masing-masing individu menggunakan prinsip agama untuk menuntun dirinya dalam kehidupan di masyarakat, tetapi tidak masih belum bisa berbagi pengertian dari keyakinan agamanya pada pihak lain.

\section{2) Kepercayaan}

Unsur yang tak kalah penting dalam kehidupan bersama adalah kepercayaan. Dalam masyarakat yang majemuk/plural selalu memikirkan resiko terhadap berbagai perbedaan. Munculnya resiko dari rasa kecurigaan/ketakutan atau ketidakpercayaan terhadap yang lain dapat timbul ketika tidak ada komunikasi yang baik di dalam masyarakat majemuk/plural.

\section{3) Toleransi}

Toleransi merupakan bentuk tertinggi yang menyatakan bahwa individu dapat mencapai keyakinan. Toleransi dapat menjadi kenyataan ketika seseorang menerima dan mengasumsikan adanya perbedaan.

\section{Pentingnya Toleransi dalam Pendidikan Multikulturalrisme}

Pendidikan multikultural dapat membantu siswa/mahasiswa untuk mengakui ketepatan dari berbagai pandangan budaya yang beragam, membantu siswa/mahasiswa dalam mengembangkan kebanggaannya terhadap warisan budaya mereka, menyadarkan siswa/mahasiswa bahwa konflik nilai sering kali menjadi penyebab konflik antar kelompok masyarakat (Savage \& Armstrong, 1996). Pendidikan multikultural ini diselenggarakan atas upaya mengembangkan kemampuan siswa/mahasiswa dalam memandang kehidupan dari berbagai perspektif budaya yang berbeda dengan budaya yang mereka miliki, serta bersikap positif terhadap perbedaan budaya, ras, dan etnis. (Farris \& Cooper, 1994). ${ }^{\mathbf{1 1}}$

Dalam menerapkan pendidikan multikultural tentu kita harus memahami dan mempelajari konsepnya, terutama dalam menjaga toleransi melalui sistem pendidikan tersebut. Penulis menyarakan beberapa cara melalui analisis studi litelatur kami, yaitu mendalami arti toleransi dalam pembelajaran, memberikan diskusi mengenai ragam

${ }^{11}$ Mukodi. 1994. Konsep Pendidikan Berbasis Multikultural Ala Ki Hadjar Dewantara. 
kebudayaan, meningkatkan kepedulian pada ranah sosial, serta berusaha membuka pola pemikiran siswa/mahasiswa agar tidak terjadi echo chamber.

\section{a. Mendalami arti toleransi dalam pembelajaran}

Memberikan pendalaman terhadap arti toleransi kepada siswa/mahasiswa merupakan langkah awal yang tepat untuk memberikan pelajaran, terutamanya pada masyarakat majemuk. Untuk hidup dalam perbedaan, hati yang sempit dan tingginya egoisme diri sama sekali tak dibutuhkan ${ }^{12}$. Kemajemukan adalah suatu kekayaan dan toleransi sendiri merupakan suatu jembatan yang akan membawa kita menuju kejayaan. Oleh karena itu, mendalami arti toleransi pada sistem Pendidikan Multikultural sangat penting bagi masyarakat majemuk seperti bangsa Indonesia ini.

Menurut Arif (2020), toleransi bukan hanya mengenai sebuah sikap, melainkan juga merupakan kerendahan hati dan keterbukaan pikiran ${ }^{13}$. Toleransi dapat memberikan arti penting dalam mendalami pemahaman agama serta penghayatan sosial, utamanya pada keberagaman. Hal tersebut akan terwujud jika kita memahami konsep toleransi dengan baik dan benar, serta mau menerapkannya.

\section{b. Memberikan diskusi mengenai ragam kebudayaan}

Sejak awal Indonesia memang sudah memiliki banyak ragam budaya. Memahami ragam kebudayaan hanya berdasarkan materi dan teori saja tidaklah cukup. Perlu praktek yang tepat dalam mempeljarinya. Diskusi merupakan sebuah langkah yang sederhana dan tepat bagi sistem pendidikan multikultural ketika siswa/mahasiswa tidak dapat berinteraksi langsung dengan ragam kebudayaan tersebut. Bahkan, "Bhineka Tunggal Ika" seakan menjadi sebuah motto hidup dan semboyan bangsa Indonesia, walaupun dalam era globalisasi seperti ini. ${ }^{14}$

Dialog merupakan cara terbaik dan ampuh dalam mengatasi ragam kebudayaan serta perbedaan yang muncul. Perbedaan ini tentu seringkali muncul dalam masyarakat majemuk seperti bangsa Indonesia. Menurut Al-Qurturby (2017), menerima perbedaan dan mengakomodasi perbedaan sangatlah penting untuk mnciptakan suasana toleransi. Oleh karena itu, diskusi merupakan saran yang tepat untu menyalurkan semua itu.

Keberhasilan siswa/mahasiswa dalam mengahadapi berbagai isu dan pemikiranpemikiran mengenai perbedaan tentulah sangat penting. Hal tersebut dapat menyebabkan kesatuan dan solidaritas bangsa lebih erat. Akan tetapi, hasil dari diskusi tidak akan berfungsi secara optimal apabila tidak dilakukan secara berkesinambungan.

\section{c. Meningkatkan kepedulian pada ranah sosial}

Membangun suasan yang humanis antar individu merupakan suatu hal yang dasar dalam menciptakan kepedulian ${ }^{15}$. Darmiyati Zuchdi (2011: 170) menjelaskan bahwa, kepedulian sosial merupakan suatu sikap dan tindakan yang selalu ingin memberi bantuan kepada masyarakat membutuhkan. Hal tersebut sangat berpengaruh terhadap perasaan seorang anak. Pendidikan multikultural tentu akan memperhatikan sifat ini demi terwujudnya pendidikan tanpa memandang latar belakang pelajar. Dapat disimpulkan,

\footnotetext{
12 Mahfud, Al. 2016. Mendalami Makna Toleransi. https://analisadaily.com/berita/arsip/2016/12/9/284503/mendalami-makna-toleransi/

13 Admin. 2020. Toleransi Itu Soal Kerendahan Hati dan Keterbukaan Pikiran. http://psikologi.uinjkt.ac.id/toleransi-itu-soal-kerendahan-hati-dan-keterbukaan-pikiran/

14 UKP. 2017. Menghargai Keberagaman dalam Diskusi "Satu Indonesia". http://unpar.ac.id/menghargaikeberagaman-dalam-diskusi-satu-indonesia/

15 Santoso, Budi. 2016. Kepedulian Sosial Untuk Mempertahankan Nilai-Nilai Moral. http://eprints.ums.ac.id/47745/15/NASKAH\%20PUBLIKASI.pdf
} 
bahwa kepedulian sosial adalah suatu sikap yang selalu ingin membantu orang lain yang membutuhkan serta dilandasi oleh rasa kesadaran (Malik, 2008: 423). ${ }^{16}$

\section{d. berusaha membuka pola pemikiran siswa/mahasiswa agar tidak terjadi echo chamber}

Echo chamber dapat diartikan sebagai sebuah ruangan yang hanya kita denngar tanpa mau tahu atau tanpa peduli dengan keadaan yang sebenarnya ${ }^{17}$. Dalam media berita, echo chamber merupakan sebuah deskripsi kiasan sebuah keadaan dimana suatu keyakinan yang diyakini atau disebarkan oleh uatu komunitas tertntu dan diulang-ulang dalam sebuah sistem tertutup. Akan tetapi, hal tersebut memiliki potensi untuk menjadi bias konfirmasi. Hal ini justru dapat meningkatkan polarisasi dan memancing ekstrimisme sosial dan politik.

Pendidikan multikultural dapat mencegah pandangan ini melalui pembelajaran sedini mungkin. Dengan sistem pendidika multikultural, siswa akan belajar bagaiamana suatu keyakinan dapat hidup berdampingan dengan keyakinan lain tanpa perlu merusak suatu keyakinan tertentu. Dengan begitu, masyarakat akan terus memandang setiap perbedaa dengan baik tanpa menyalahkan satu pandangan tertentu saja.

\section{SIMPULAN}

Toleransi merupakan kunci utama bangsa Indonesia dalam mewujudkan kesatuan dan persatuan akan kebergaman. Toleransi berarti memberikan suatu kompensasi atau kesempatan terhadap suatu perbedaan. Toleransi adalah sebuah sikap atau sifat yang menghargai dan menghormati perbedaan tersebut.

Pedidikan Multikutual adalah suatu sistem pendidikan yang memakai konsep plularisme dan menekankan kepada prinsip-prinsip kesamaan. SARA bukanlah suatu permasalahan jika dipandang dari kaca mata pedidikan multikultural. Pedidikan multikultural merupakan jalan emas yang membangun sikap toleransi. Pendidikan mulyikultural dan toleransi merupakan dua hal yang berkesinambungan dan tak dapat terpisahkan.

Pentingnya pendidikan multikultural adalah untuk menjaga sikap toleransi dalam diri seseorang. Pedidikan multikultural juga dapat mengakhiri perbedaan pendapat mengenai keragaman budaya, suku, ras, etnis, agama, bahasa, dan lain sebagainya. Penulis menyarakan beberapa cara melalui analisis studi litelatur kami, yaitu mendalami arti toleransi dalam pembelajaran, memberikan diskusi mengenai ragam kebudayaan, meningkatkan kepedulian pada ranah sosial, serta berusaha membuka pola pemikiran siswa/mahasiswa agar tidak terjadi echo chamber.

\section{DAFTAR PUSTAKA}

Melfianora. 2010. Penulisan Karya Tulis Ilmiah Dengan Studi Literatur. file:///C:/Users/ACER/Downloads/KTI\%20dengan\%20Studi\%20Literatur.pdf

Kelas Pintar. 2019. Mengenal Jenis-Jenis Metode Penelitian. https://www.kelaspintar.id/blog/edutech/jenis-metode-penelitian-2566/

Ibrahim, Rustam. 2013. Pendidikan Multikultural: Pengertian, Prinsip, dan Relevansinya dengan Tujuan Pendidikan Islam. https://journal.iainkudus.ac.id/index.php/Addin/article/view/573/586.

16 Tabi'in, Ahmad. 2015. Menumbuhkan Sikap Peduli Pada Anak Melalui Interaksi Kegiatan Sosial. file://C:/Users/ACER/Downloads/3100-10177-1-SM.pdf

17 Ardiansyah Okky. 2019. Echo Chamber, Arti dan Bahayanya di Dunia Maya. https://www.pikiranrakyat.com/teknologi/pr-01310389/echo-chamber-pengertian-dan-bahayanya 
Ibrahim, Rustam. 2013. Pendidikan Multikultural: Pengertian, Prinsip, dan Relevansinya dengan Tujuan Pendidikan Islam. https://journal.iainkudus.ac.id/index.php/Addin/article/view/573/586

nn. 2020. Kamus Besar Bahasa Indonesia (KBBI).

Aditya, Ivan. 2017. Politik Toleransi. https://www.krjogja.com/angkringan/opini/politiktoleransi/

Nugroho, Fauzan Tri. 2020. Pengertian Toleransi Secara Umum dan Menurut Ahli, Ketahui Jenis-jenisnya. https://www.bola.com/ragam/read/4409596/pengertian-toleransi-secaraumum-dan-menurut-ahli-ketahui-jenis-jenisnya.

Aditya, Ivan. 2017. Politik Toleransi. https://www.krjogja.com/angkringan/opini/politiktoleransi/

Triyani, Ely Mei. 2016. Perbedaan Toleransi Antar Umat Beragama Pada Penganut Islam Dan Hindu Di Desa Kongkong Kecamatan Mijen Kota Semarang. https://lib.unnes.ac.id/28734/1/1511412114.pdf

Mukodi. 1994. Konsep Pendidikan Berbasis Multikultural Ala Ki Hadjar Dewantara.

Mahfud, Al. 2016. Mendalami Makna Toleransi. https://analisadaily.com/berita/arsip/2016/12/9/284503/mendalami-makna-toleransi/

Admin. 2020. Toleransi Itu Soal Kerendahan Hati dan Keterbukaan Pikiran. http://psikologi.uinjkt.ac.id/toleransi-itu-soal-kerendahan-hati-dan-keterbukaan-pikiran/

UKP. 2017. Menghargai Keberagaman dalam Diskusi "Satu Indonesia". http://unpar.ac.id/menghargai-keberagaman-dalam-diskusi-satu-indonesia/

Santoso, Budi. 2016. Kepedulian Sosial Untuk Mempertahankan Nilai-Nilai Moral. http://eprints.ums.ac.id/47745/15/NASKAH\%20PUBLIKASI.pdf

Tabi'in, Ahmad. 2015. Menumbuhkan Sikap Peduli Pada Anak Melalui Interaksi Kegiatan Sosial. file:///C:/Users/ACER/Downloads/3100-10177-1-SM.pdf

Ardiansyah Okky. 2019. Echo Chamber, Arti dan Bahayanya di Dunia Maya. https://www.pikiran-rakyat.com/teknologi/pr-01310389/echo-chamber-pengertian-danbahayanya

-------2010. Pendidikan Berbasis Multikultural.

(http://www.educationindonesia.n et/), diakses 20 April 2010.

------.2009. Bagaimana Mengembangan Pembelajaran Berbasis Multikultural. http://waraskamdi.com/, diakses 15 maret 2010.

--------2009. Pembelajaran Berbasis Multikultural. http://lubisgrafura.wordpress.com, diakses tanggal 15 Maret 2010.

Azwar, Zaifuddin, 2010. Metodologi Penelitian, Yogyakarta: Pustaka Pelajar. , 2010. Penyusunan Skala Psikologi, Yogyakarta: Pustaka Pelajar.

Choirul Mahfud , 2009, Pendidikan Multikultural, Yogyakarta: Pustaka Pelajar.

Freire, Paulo. 2000. Pendidikan Pembebasan. Jakarta: LP3S.

Hernandez, Hilda. 2002. Multikultural Education: A Teacher Guide to Linking Context, Process, and Content. New Jersey \& Ohio: Prentice Hal

Sutarno. 2008. Pendidikan Multikultural. Jakarta: Direktorat Jendral Pendidikan Tinggi Departemen Pendidikan Nasional.

Welianto, Ari. 2020. Tujuan dan Manfaat Toleransi. https://www.kompas.com /skola/read/2020/03/06/170000769/tujuan-dan-manfaat-toleransi?page=all 